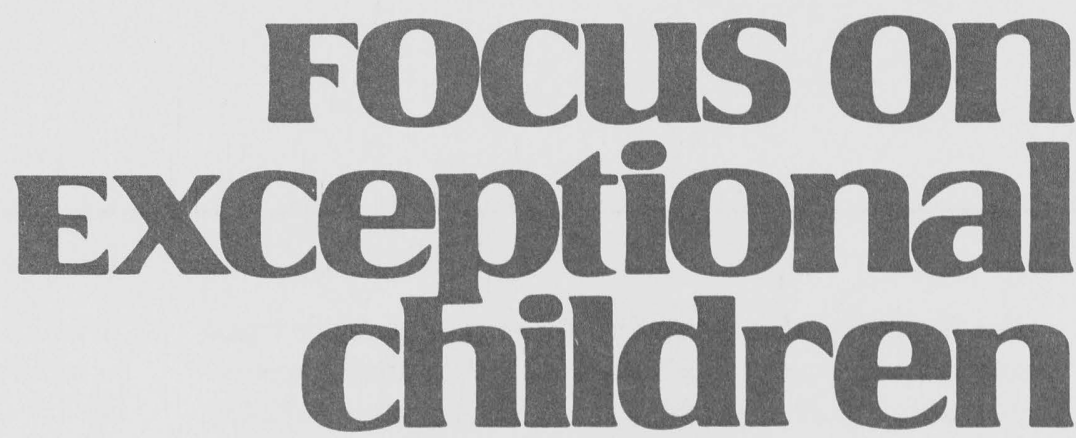

\title{
Considerations in Teaching Higher Order Thinking Skills To Students with Mild Disabilities
}

\author{
Prisca R. Moore, Herbert Rieth, and Matthew Ebeling
}

Teachers are becoming increasingly aware of and striving to teach students higher order thinking skills. Still, some educators argue that schools ought to be doing an even better job of teaching these skills because changing employment demands in our society are not being met, students are ill prepared to work in an information age, college preparation is less than satisfactory, and general problem-solving abilities are low (Resnick, 1987). Generally, employers are looking for people who possess general skills such as the abilities to write and speak effectively, to learn on the job, to read material, and to build and evaluate arguments. Schools are failing to produce individuals who can move easily into more complex types of work.

Nickerson (1987) proposes that teaching thinking skills will equip people to compete successfully for educational opportunities, jobs, recognition, and rewards in our society. In addition, good thinking is considered a prerequisite for good citizenship because critical thinking ability "helps the citizen to form intelligent judgments on public issues and thus contribute democratically to the solution of social problems" (Glaser, 1985, p. 27). The ability to think well also contributes to an individual's psychological well-being because good thinkers tend to be better adjusted than people who are not good thinkers. Finally, our citizens must possess critical thinking skills to be able to handle the many problems the world community faces (Glaser, 1985).

Though the importance of thinking skills is not debatable, Resnick (1987) and others note that thinking skills resist precise definition. Resnick incorporated key features of higher order thinking into a capsulized definition that will guide the use of this term in this article.

\begin{abstract}
Higher order thinking involves a cluster of elaborative mental activities requiring nuanced judgment and analysis of complex situations according to multiple criteria. Higher order thinking is effortful and depends on self-regulation. The path of action or correct answers are not specified in advance. The thinker's task is to construct meaning and impose structure on situations rather than to expect to find them already apparent." (p. 44)
\end{abstract}

Given the emerging societal importance of teaching higher order thinking skills, we will review special considerations in teaching these skills to students with disabilities.

\section{CURRICULUM IMPLICATIONS OF HIGHER ORDER THINKING}

Integrating higher order thinking skills into the instructional curriculum is not concerned so much with specific teaching strategies or classroom organization as it is with a different foundation for teaching. Fundamentally, it has to do with a cognitive approach to instruction that recognizes the learner as the most important element in the teaching-learning situation-more important than materials, lessons, teachers, or other factors external to the learner (Reid \& 
Hresko, 1981). This view of learning proposes that learners must play an active role in acquiring and organizing knowledge and skills (Bransford \& Vye, 1989; Champagne, Klopfer, \& Gunstone, 1985; Pea \& Soloway, 1987; Reid \& Hresko, 1981; Resnick, 1987). This includes learning by acting and experiencing the consequences of actions, observing others, imitating models, watching television, seeing demonstrations, discussing issues, and listening to lectures (Reid \& Hresko, 1981). The approach recognizes that learners construct their own meaning based on their own experiences. Therefore, effective instruction must provide learning situations that facilitate the learner's ability to construct meaning from experience.

Cognitive researchers are concerned with the traditional questions of teaching: how to present and sequence information, how to organize practice, how to motivate students, and how to assess learning (Resnick \& Klopfer, 1989). These questions, however, are being addressed differently because the focus of instruction becomes the learners' active creation of their own knowledge. The final goal of instruction becomes one of enabling learners to acquire meaningful knowledge that is activated and applied when appropriate.

As most educators know, this goal is difficult to attain. Designing instruction to attain this goal requires an understanding of how learners acquire knowledge and then develop the

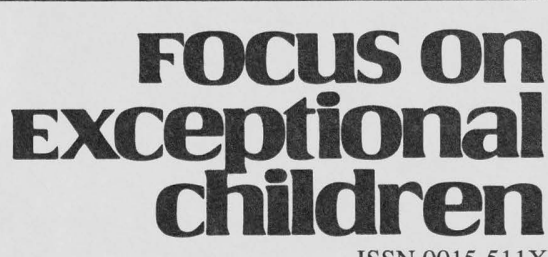

ISSN 0015-511X

FOCUS ON EXCEPTIONAL CHILDREN (USPS 203-360) is published monthly except June, July, and August as a service to teachers, special educators, curriculum specialists, administrators, and those concerned with the special education of exceptional children. This publication is annotated and indexed by the ERIC Clearinghouse on Handicapped and Gifted Children for publication in the monthly Current Index to Journals in Education (CIJE) and the quarterly index, Exceptional Children Education Resources (ECER). It is also available in microfilm from Xerox University Microfilms, Ann Arbor, MI. Subscription rates: Individual, \$27 per year; institutions, \$36 per year. Copyright (c) 1993, Love Publishing Company. All rights reserved. Reproduction in whole or part without written permission is prohibited. Printed in the United States of America. Second class postage is paid at Denver, Colorado. POSTMASTER: Send address changes to:

Love Publishing Company

Executive and Editorial Office

1777 South Bellaire Street

Denver, Colorado 80222

Telephone (303) 757-2579

Edward L. Meyen

University of Kansas
Glenn A. Vergason Georgia State University

Richard J. Whelan

University of Kansas Medical Center

Stanley F. Love

Publisher
Holly T. Rumpler

Senior Editor ability to access and apply that knowledge when appropriate. In addition, learners themselves have to understand that they must be active in their own learning, that they are responsible for their own learning and must regulate their development of knowledge. Furthermore, if learners must accept the responsibility for learning, the issue of what motivates individuals to learn becomes critical for teachers. Individual learners' motivation not only reflects their intrinsic values and beliefs but also the values of the social context in which learning is to take place.

\section{FOUR PRINCIPLES OF INSTRUCTION}

A review of four principles of instruction, based upon cognitive research, might be useful in designing instructional programs for students with special learning needs. These principles describe a constructivist view of learning that recognizes the critical, central role of the learner in the learning process by:

- considering students' prior knowledge and the preconceptions they bring regarding demands of the learning task.

- developing students' ability to form connections between new and existing knowledge so they can activate and apply the knowledge when appropriate.

- promoting self-regulated learning.

- establishing a social context in the classroom that supports the development of active learning.

\section{Prior Knowledge}

Learning is a personal process in which each person constructs new knowledge. It is an elaboration of past experience, not just the acquisition of skills and concepts (Reid \& Hresko, 1981). Previous knowledge and experiences serve as the starting point for new learning. Cognitive science heavily emphasizes what individual children bring to the learning situationboth their prior experiences and what meanings the children constructed from those experiences (Ausubel, Novak, \& Hanesian, 1978; Reid \& Hresko, 1981).

Attempts have to be made to understand the learner's representation of the learning activity or task (Palincsar, 1990). Students experiencing academic difficulty often display an impoverished conceptualization of learning. Students frequently do not understand how to learn and what being a successful learner requires. Examining the preconceptions, and possibly misconceptions, of learners regarding the learning task and the learning process itself is a critical first component in understanding the learner. To build on and expand students' knowledge of how to successfully complete learning tasks, teachers must understand what preconceptions about the learning task students bring to the classroom. These preconceptions allow the students to apply whatever knowledge they have toward performing the task successfully (Bransford \& Vye, 1989; Pea \& Soloway, 1987). 


\section{Acquiring and Using Knowledge}

\section{Developing Connections Between New and Prior Knowledge}

To know something is not just to have received information but also to have interpreted it and related it to other knowledge (Resnick \& Klopfer, 1989). In addition, those authors suggested that to be skilled is not just to know how to perform some action but also to know when to perform it and to adapt the performance to varied circumstances. If students can develop connections between their knowledge and when to use that knowledge appropriately, their knowledge will begin to become generative. Generative knowledge-the ability to activate and apply knowledge to interpret new situations, to solve problems, to think, and to reason-is the final outcome desired in the learning process (Resnick \& Klopfer, 1989).

To reach this generative level of knowledge, learners must develop and use higher order thinking skills. They must elaborate and organize what they are told, examine new knowledge in relation to their existing knowledge, and then build new connections in their knowledge structure between their new and existing knowledge (Resnick \& Klopfer, 1989). For example, students can be taught to use a computer data base-a set of skills and procedures to search for and locate information. Until the student understands that a data base is simply an efficient way to store and organize information, that they can access and use numerous data bases to locate information, and that the procedures they learned can be generalized to these other data bases, their knowledge and skills are not generative.

\section{Facilitating the Recall of Knowledge}

Knowledge is useful only to the extent that it can be recalled when needed. Bransford, Sherwood, Vye, and Rieser (1986) proposed an important prerequisite for competence in using knowledge: Knowledge must be activated, or accessed, when needed. Although students may have acquired knowledge relevant to a specific situation, no guarantee exists that students will access it when the situation arises. For example, students may memorize the formula for calculating area, but when faced later with determining how large to make a basketball court on their driveway, they do not use this formula. This represents a lack of understanding of when knowledge (e.g., the formula for calculating area) is relevant to a particular situation. They fail to see the connection and, therefore, miss the opportunity to apply their knowledge.

Students must be given explicit instruction to use the learned skills in a variety of situations. Further, they must be taught how to identify new problem situations in which they should apply the knowledge and skills they have mastered. The formula for calculating the area of rectangular surfaces applies not only to the basketball court but also to the size of a rug and many other situations. Students must understand that skills and procedures learned in school relate to realworld circumstances. The teacher must go beyond introduc- ing the concept of area in geometry and having students calculate the area of various geometric figures. They must discuss how geometric shapes (e.g., rectangles and squares) are similar to shapes students will encounter in the real world. Students often do not recognize that they can use formulas taught in school in real life.

Many students do not connect the knowledge and procedures they learn in school, particularly in mathematics, with the problems they encounter in everyday life. Therefore, teachers must explicitly discuss and demonstrate how skills and procedures taught in school can be and should be used to solve problems in the real world.

Many cognitive researchers argue that effective learning requires students to spend more time actively using knowledge to solve problems and less time simply being introduced to facts and concepts. Students must have the opportunity to actively use their new knowledge and to experience directly its effects on their own performance (Bransford \& Vye, 1989). Further, if students do not have the opportunity to use new information to achieve specific goals, they often learn facts that can be recalled only in specific contexts and otherwise remain "inert" (Whitehead, 1929). Failure to generalize knowledge to new situations is a notorious weakness in education.

The constructivist view of learning suggests that learners must actively construct new knowledge (Bransford \& Vye, 1989; Champagne, Klopfer, \& Gunstone, 1985; Pea \& Soloway, 1987; Resnick, 1987). This view recognizes that learners are not simply recorders of information but, instead, builders of knowledge structures (Resnick \& Klopfer, 1989). The goal is for learners to construct their knowledge structures so they form connections between their declarative and procedural knowledge to create knowledge that is generative. For knowledge to be generative, learners must be able to access and apply that knowledge when appropriate. This critical development of connections between existing and new knowledge depends, to a large extent, on learners' awareness and regulation of their learning.

\section{Self-Regulated Learning}

Effective learners assume responsibility for their learning (Palincsar \& Brown, 1989). In addition, they regulate their learning by managing, monitoring, and evaluating. Self-regulated learners are able to use three main types of knowledge in a flexible manner: (a) metacognition; (b) the ability to develop strategies for accomplishing learning tasks efficiently; and (c) real-world knowledge (Brown, Campione, \& Day, 1981; Palincsar \& Brown, 1989; Pressley, Borkowski, \& Schneider, 1987).

\section{Metacognition}

The success of self-regulatory activity reflects what we know of our own learning characteristics and the task de- 
mands (Palincsar \& Brown, 1989). This type of knowledge often is called metacognition. Resnick (1987) described metacognitive skills as processes that play an "executive" or selfmonitoring role in which students: (a) keep track of their own understanding, (b) initiate review or rehearsal activities when needed, and (c) deliberately organize their attention and other resources to learn something. Palincsar and Brown (1989) proposed that metacognitive knowledge enables a learner to select, employ, monitor, and evaluate the use of strategies. Metacognitive instruction focuses on teaching students general techniques for remembering and summarizing content material (Schumaker, Deshler, \& Ellis, 1986).

Paris and Winograd (1990) identified two essential features of metacognition: (a) self-appraisal and (b) self-management of cognition. Self-appraisal answers questions about what learners know, how they think, and when and where they should apply knowledge and strategies. Self-management refers to metacognition in action or how metacognition can orchestrate cognitive aspects of learning. It is reflected in the plans learners make before tackling a task, in the adjustments they make as they work, and in the revisions they make afterward.

\section{Developing Strategies for Accomplishing Tasks}

The plans students make to guide their learning can be described as their learning strategies. The term learning strategy describes a range of activities from specific learning tactics, such as rehearsal and elaboration, to more general types of self-management activities, such as planning and comprehension monitoring, to complex plans that combine several specific techniques.

Derry (1990) argued for drawing a distinction between specific learning tactics and the learning strategies that use them. She suggested that a learning strategy is the complete plan one formulates for accomplishing a learning goal, whereas a learning tactic is any individual processing technique one uses in service of the plan. For example, typical learning tactics taught in reading instruction are skimming, scanning, and possibly the application of a technique such as SQ3R (in which students are asked to Survey, Question, Read, Recite, and Review). A learning strategy is the plan students develop when they are assigned a reading task such as reading a chapter to prepare for a quiz.

Students may use any or all the learning techniques listed above when reading the text and preparing for the quiz. In forming their learning strategy, the students select from a wide range of techniques they might be familiar with and select those they believe will be most effective in reading the text and preparing for the quiz. This leads to the creation of a learning strategy. Thus, a learning strategy can be viewed as the application of one or more specific learning tactics to a learning problem.

\section{Real-World, Meaningful Knowledge}

A cognitive instructional framework focuses on meaningful, real-world issues and problems. Real-world problems are used because the real-world environment is already a part of the child's schematic network of knowledge (Lesh, 1981). Using a real-world environment provides opportunities to link knowledge to the child's everyday world and experiences. Englert, Tarrant, and Mariage (1992) pointed out that students frequently are taught basic skills through lessons that emphasize recitation and seatwork and that break apart the components in such a way that they are detached from meaningful and functional activities. They suggested that special education programs often focus on task analyzing and teaching the isolated components of a cognitive process without simultaneously letting the students participate in the whole cognitive process. For example, students may be taught the skills of addition and subtraction in isolation through the use of drill-andpractice sheets. When presented with a real-world task of balancing a checkbook, however, they may have little or no understanding that these skills taught in isolation should be applied to this problem-solving situation.

Although instruction in basic skills is important, it must go hand-in-hand with opportunities to work on tasks that model the real world of problem solving (Englert et al., 1992). Teachers must be viewed as agents who assist students in becoming thinkers and involve students in the whole problemsolving enterprise. If students are to become thinkers, teachers must emphasize higher order thinking, present strategies and skills in holistic or natural contexts, incorporate authentic, real-world purposes and goals into learning tasks, and integrate instruction across the curriculum (Anderson, 1989; Englert et al., 1992; Lampert, 1990).

\section{Promoting Self-Regulated Learning}

How can one best impart to students certain metacognitive skills and learning strategies? Harris and Pressley (1992) outlined a seven-stage procedure for teaching students self-instructional strategies with the goal of autonomous, reflective use of effective strategies. Those authors caution that the seven basic stages are not meant to be followed in a "cookbook" fashion. Instead, they offer a general format and guidelines.

1. The student masters any preskills necessary for understanding and using the targeted strategy.

2. The teacher and the student examine any strategies the student currently uses. They discuss the significance and potential benefits of the proposed strategy and establish goals in a positive, collaborative manner.

3. The teacher describes the executive strategy (i.e., steps in prewriting or revision), advantages of this strategy, and how and when to use the strategy.

4. The teacher (or peer) models the strategies to be learned in context. The teacher and the student then discuss the 
model's performance, and the student generates and records self-instructions for each strategy modeled, making any changes that may make the strategy more efficient or effective for that student.

5. The student memorizes the self-instructions and steps in the strategy.

6. The student practices the strategy and self-instruction while performing the task. Prompts, interaction, and guidance are faded over practice sections until the student achieves independent performance.

7. The student is encouraged to use the strategy independently. Self-regulation procedures are continued, and plans for transfer and maintenance are implemented.

Harris and Pressley proposed that these seven instructional stages are recursive and can be reordered. Each student plays an active role as a collaborator in determining the goals of instruction; completing the task; and implementing, evaluating, and modifying the strategies. Teachers gradually reduce their input at a pace that permits competent performance by the students through the instructional sequence.

Becoming self-regulated learners can produce the knowledge and confidence that enable learners to manage their own learning, and it empowers them to be inquisitive and persistent in their efforts (Paris \& Winograd, 1990). Self-regulated learning, however, is extremely work-intensive, and motivation for this activity must be viewed as an integral part of instruction (Palincsar \& Brown, 1989; Resnick \& Klopfer, 1989). An important part of the teacher's job is to help children accept challenge and want to develop active knowledge notwithstanding the effort involved (Schoenfield, 1989).

\section{Impact of Social Setting}

The social context in which instruction takes place must actively support the development of self-regulatory knowledge. The classroom must encourage the development of active learning. Pogrow (1990) proposed the social experience approach, which entails creating situations in which students come to experience the need to think and begin to share their perceptions of the thinking process with each other. He argued that classrooms must become learning environments wherein students are motivated to solve problems and come to realize the value of, and the need for, understanding relevant processes and information. This is at the core of creating learning situations that develop active learning.

In the social setting, learners must come to know that all the elements of critical thought-interpretation, questioning, trying possibilities, demanding rational justifications - are socially valued (Resnick \& Klopfer, 1989). Through participation in settings such as this, learners will come to expect to think all the time, to view themselves as able, even obligated, to engage in critical analysis and problem solving. The social community plays a critical role in shaping dispositions for thinking (Pogrow, 1990).

Effective teachers involve students in classroom dialogues about cognitive processes (processes involved in completing the task, such as comprehending a reading passage, writing a story, or solving a mathematical problem) and learning strategies (including the specific learning techniques to be used to complete the task) (Englert, Tarrant, \& Mariage, 1992). Further, the role of teachers is to model and think-aloud the thoughts and strategies of a skilled learner and problem solver. Teachers need to orchestrate classroom dialogue or conversation that leads to a common vocabulary and a set of assumptions about the processes and strategies involved in completing the task. This classroom discourse must initiate the students into the language, processes, constraints, repertoire of examples, actions, and thoughts of a skilled problem solver. Teachers facilitate this language and vocabulary for thinking and problem solving by modeling the inner dialogue they use while performing the task (i.e., in writing, describing the decisions they make as they go through the steps in writing a paper, including brainstorming for ideas, planning an outline, writing the rough draft, and revising and editing).

The purpose of this classroom dialogue between teachers and students is to provide an opportunity for the teacher to model the behavior of a skilled problem solver and to "talk through" the steps in performing a certain task. This type of classroom dialogue will require changes in how the lesson is conducted, with greater reliance on group work and talk that is more like a conversation or dialogue than a monologue in which the teacher presents information and tests students' retention of that information (Englert et al., 1992). In a classroom dialogue the emphasis is on the students' talk or conversation about strategies and processes rather than a recitation of basic facts. Students are encouraged to ask questions and respond to problems. The teacher promotes students' mastery of cognitive strategies by modeling strategies in authentic, meaningful contexts, cuing students to activate and monitor their own use of strategies and, in doing so, gradually transferring control of the dialogue and strategies to the students.

Englert et al. (1992) set forth the steps involved in creating classroom dialogues by analyzing the classroom discourse involved in instruction in writing.

1. The teacher models his or her own thinking and introduces new strategies and language necessary for performing the task or solving the problem. Students are instructed in new procedures and strategies as needed to perform the assigned task so instruction is embedded in meaningful contexts rather than presented in isolation (e.g., editing symbols and strategies are presented as students edit the writing on the classroom message board or in the class newsletter).

2. The teacher promotes classroom talk that appears like conversation among students as they work together to perform 
the task. This should not be a monologue in which the teacher thinks aloud about strategies or gives instructions but, instead, a dialogue that the students truly construct in the group.

3. The teacher involves all students in the task even though the students are at various levels in their ability to engage in the process of performing the task independently. Students provide different contributions and make sense of the activity in different ways depending on their knowledge and experiences. Through participation, students are able to see the entire writing process and how it works, understand how the steps fit together, and gain an understanding of the purposes, strategies, and goals of performing the task.

4. The teacher prompts the students to take ownership of the cognitive processes involved in performing the task by making them informants and experts. The students are charged with the responsibility of serving as informants to the teacher and peers (helping them identify and use strategies necessary for performing the task), and they begin to assume the composing and self-regulating activities of an expert writer.

5. The teacher cues the students to internalize, appropriate, and transform the language and strategies introduced. The teacher must decrease the amount of modeling and prompt the students to make the strategy their own knowledge.

6. The teacher uses relinquishing strategies to prod his or her students into performing self-regulatory functions. Relinquishing strategies include: (a) asking students to take over and run the task themselves; (b) asking students to think aloud as they perform the task, to identify the processes and strategies they are using; (c) having students justify their strategies; and (d) encouraging students to turn to their peers for assistance or information. These relinquishing strategies prompt the students to assume increasing control of the processes and strategies involved in completing the task - a critical step in the development of selfregulated learners.

\section{ANCHORED INSTRUCTIONAL APPROACH TO TEACHING HIGHER ORDER THINKING SKILLS}

Carnine (1991) advocates major curricula modifications to enhance the acquisition of higher order thinking processes by all students. He argues that many interventions, including efficient teaching techniques, cooperative learning, and metacognitive strategy training, are undermined when curricular materials focus on rote learning. Although he considers the acquisition of basic requisite knowledge important, he points out that exposing the students with disabilities to instructional materials that require higher order thinking is equally important.
One interesting line of research on thinking skills has been conducted by the Cognition and Technology Group at Vanderbilt (CTGV). To develop meaningful knowledge accessible by learners with disabilities, Bransford, Sherwood, Hasselbring, Kinzer, and Williams (1990) suggest using realworld problem situations as instructional anchors. Anchored instruction emphasizes the importance of situating or anchoring instruction in meaningful problem-solving environments. The basis of this approach is to create semantically rich "anchors" that illustrate important problem-solving situations. These anchors create a "macrocontext" that provides a common ground for teachers and students from diverse backgrounds to explore issues and communicate in ways that build collective understanding (Bransford et al., 1990; Cognition and Technology Group at Vanderbilt, in press). Macrocontexts are problem-rich environments that can be used to integrate concepts across the curriculum and in which meaningful, authentic problems can be posed and explored (Cognition and Technology Group at Vanderbilt, in press).

This approach represents a dramatic change from the traditional classroom curriculum. Rather than isolated instruction in the traditional discipline areas, all classroom instruction centers on solving a problem or series of problems. The skills and concepts introduced in class, as well as students' prior knowledge, take on new meaning in this problem-rich instructional environment. In the traditional mode, students simply memorize factual information with little appreciation of how facts simplify problem solving. They treat knowledge as the end rather than as means to important ends. Concepts and procedures frequently are introduced independently of the context in which they are useful. In contrast, when students encounter naturally occurring problems that create a need for the new information, it reinforces for them the usefulness of knowledge and skills as problem-solving tools.

As an example, Moore (1988) developed an instructional program designed to teach scheduling skills to students with mild disabilities. This program was developed from a realworld problem-solving context that appealed to the students and offered some intrinsic motivation for them to master the problems in that context. In addition, the students preferably had experience with that context. With these considerations in mind, the context selected was the Opryland Amusement Park in Nashville, Tennessee. This context offered a rich source for motivating students to solve real problems in the area of scheduling. Because this park was a local attraction; the reasonable assumption was that students could have been to the park or certainly had heard and seen advertisements for the park.

Opryland officials gave permission to videotape the park. This videotape, along with the students' prior knowledge about amusement parks in general and Opryland specifically, provided a common contextual background for the problems to be presented. The teacher used this common background to 
discuss students' preconceptions about amusement parks and why scheduling is important in that context. For example, the teacher asked the students to remember if they had been able to ride all the rides or visit all the attractions they wanted to when they went to an amusement park. This led to a discussion of how they could do only so much in a given time and had to make decisions about how to use their time. The teacher also pointed out on the videotape the lines at various rides and attractions and asked students to discuss how this might affect their plans. Then students were asked to solve problems that required calculating how long various activities such as rides and shows lasted and using this information to plan schedules. To solve these problems, the students had to draw upon what they knew about scheduling, as well as their skills in telling time and calculating elapsed time.

A critical reason for creating anchors for instruction is to allow students and teachers to share a common experience. A major difficulty for teachers is attempting to relate their instruction of new concepts and skills to the students' prior experiences and previously acquired knowledge. In providing instructional anchors, teachers can create contexts that can be shared with a student and also can serve as an anchor for new knowledge (Hasselbring, Goin, \& Bransford, in press). Students have the opportunity to share a set of common experiences while simultaneously exploring specific areas of personal interest (Cognition and Technology Group at Vanderbilt, in press). As students attempt to solve the problems encountered in this macrocontext, they must become actively involved in searching their existing knowledge for information or skills related to solving the problems and then identify skills they must develop to solve the problems in this new environment.

In this type of instructional environment, students begin to understand that knowledge and skills are tools for solving problems. They must actively seek out knowledge so they can answer questions, solve problems, or pursue an area of personal interest. Because the knowledge will be personally meaningful to the student, the likelihood that the new knowledge will be related to prior knowledge increases dramatically. Also, as students explore new areas of knowledge, they will have the opportunity to communicate the results of their explorations to their fellow students, teachers, and parents (Cognitive and Technology Group at Vanderbilt, in press).

For example, in Moore's (1988) instructional program developed to teach scheduling skills, the Opryland Amusement Park video anchor provided the class with a common experience and a common problem: How do you get to do everything you want in the amusement park in a given time? Students could easily understand the need for scheduling their time if they wanted to visit certain rides and shows. They were asked to develop schedules for their time in the park, considering the time involved in visiting shows and riding rides, as well as waiting in lines.
This instructional anchor could serve as a basis for many other problems, too. For example, if students focused on the animals in the petting zoo, numerous questions about the animals, their care, and their backgrounds could serve as a starting point for explorations in science and geography that require critical reading skills.

CTGV currently is investigating the use of multimedia or integrated media for developing anchors for instruction. Multimedia is an instructional delivery system that involves mixing and interweaving text, graphic images, and video to create an interactive media for presenting materials. CTGV uses the term "integrated media" because it is a reminder that the goal is to integrate media in ways that facilitate learning, not simply to multiply the number of media available to learners. Although anchors for instruction can be provided in a textual format, video-based anchors may be a potentially more powerful means of establishing this common experience for the students and teacher (Bransford et al., 1990; Hasselbring, Goin, \& Bransford, in press). Video-based anchors contain much richer sources of information than do printed media. Video is dynamic, visual, and spatial and therefore enables students to form rich mental models of problem situations more easily. Being able to see events or situations rather than just hear or read about them may improve students' memory and comprehension.

Ideally, these integrated media anchors should be built around real-world problems. The real-world environment already is part of the child's network of knowledge (Lesh, 1981). Utilizing a real-world environment provides opportunities to link knowledge to the child's everyday world and experiences. As students experience using their knowledge in a variety of real-world situations they perceive as being meaningful, they will begin to link the knowledge and real-world contexts together. Thus, when they encounter similar situations, they may apply this knowledge to the appropriate aspect of the problem.

\section{Higher Order Thinking in Reading}

Reading can be viewed as a problem-solving process. Readers attempt to discover what the author means and, at the same time, build meaning for themselves-essentially constructing their own meaning. They use their own language, their own thoughts, and their own views of the world to interpret what the author has written (Goodman \& Burke, 1981). Therefore, these interpretations are limited by what the reader knows. To decode the author's message, readers must actively interact with the print by bringing their own prior knowledge, experiences, and preconceptions about the content area of the reading material, as well as the reading process itself (Reid \& Hresko, 1981). Successful readers combine two types of reading comprehension strategies: (a) the ability to understand written texts automatically and with little effort, and (b) the capacity to apply deliberate strategies for interpreting and remembering when the need arises (Resnick, 1987). 
More successful readers have been found to have: (a) a greater awareness of the "meaningful" nature of reading; (b) better appreciation of the importance of using self-testing activities while reading; and (c) stronger recognition of the need to deploy strategies differentially depending on their purpose for reading (Brown, Palincsar, \& Armbruster, 1984; Palincsar \& Brown, 1989). Palincsar and Brown (1989) discussed strategies that facilitate reading comprehension and lead to self-regulation of reading activity. In a review of theoretical discussions of the use of strategies for understanding text, six strategies that both monitor and foster comprehension were identified:

1. Clarifying the purposes of reading to determine the appropriate approach to the reading activity.

2. Activating background knowledge to create links between what is known and the new information presented in the text.

3. Allocating attention so the major content, not trivia, becomes the focus.

4. Evaluating content critically for internal consistency and compatibility with prior knowledge and common sense.

5. Using monitoring activities such as paraphrasing and selfquestioning to determine if comprehension is occurring.

6. Drawing various kinds of inferences and testing them.

The Young Sherlock Project is a multimedia literacy project designed to help middle school students acquire important literacy skills while also learning relevant social studies content (Kinzer, Rieth, \& Singer-Gabella, 1992; Cognition and Technology Group at Vanderbilt, in press). In this project the commercially available film, The Young Sherlock Holmes, was used as the context for instruction within which students learned aspects of literacy such as characterization, cause-andeffect relationships, vocabulary, setting, plot structure, and composition. In addition to the video technology, a holistic model was used, involving author circles, cooperative learning groups, and authentic writing tasks. The above areas were integrated and taught as related parts of a whole rather than isolated parts as ends-in-themselves.

The The Young Sherlock Holmes video provides an anchor, a common reference point for teachers and students. The contextualized world created using the video moves beyond the single-sentence or single-story contexts found in classrooms to an overarching context within which instruction occurs for a sustained time. By beginning with a video environment for students to explore, Sherlock allowed even poor readers to contribute to class discussions. Furthermore, students were motivated to research various aspects of the video (e.g., to learn more about Queen Victoria, the restrictions on women who lived during that time), and therefore did a great deal of reading, writing, and communicating to fellow class members. The extended time spent working with the Sherlock video also allowed students to specialize in specific areas of interest (e.g., Queen Victoria) and be able to develop in-depth expertise.

Bransford et al. (1990) suggested that their anchored instruction approach can be used to address these problems commonly found in instructional situations. First, teachers face students whose background knowledge is limited. Second, teachers and students often have no, or limited, shared knowledge. Responding to both of these challenges, anchored instruction provides a common background shared by all participants in the class. Therefore, shared knowledge and shared points of reference can be easily used in instruction. Third, students' learning knowledge, although demonstrated in one situation, does not generalize and is not accessed or used in appropriate, new situations. Anchored instruction facilitates the integration of subject areas and it also provides students with new opportunities to notice and identify diverse problemsituations in which similar knowledge is relevant to constructing and implementing solutions. It further provides students with an overarching context or problem in which stepwise learning occurs; each step is visibly and consciously related in its importance to the overall solution. The steps are part of the whole rather than ends in themselves.

Findings from this project indicated that students not only learned the information but also used this information in new, transfer settings and in their everyday interactions, when appropriate. Students participating in this project were more motivated, better able to integrate new content, and better able to retain and use information that was taught than their peers were. Details of the Sherlock project are described elsewhere (CTGV, in press; CTGV, 1990; Bransford, Kinzer, Risko, et al., 1989).

\section{Higher Order Thinking Skills and Written Expression}

Even though the school curriculum tends to neglect writing, written expression can be a great cultivator and enabler of higher order thinking, particularly if writing is considered an occasion to think through arguments and to master forms of reasoning and persuasion (Resnick, 1987). Writing is a problem-solving process combining a number of conscious cognitive and linguistic processes such as planning, organizing, structuring, and revising (Hull, 1989).

Writing that is not read is not writing, because it ceases to be communication (Smith, Goodman, \& Meredith, 1976). Students must be given the opportunity to see that their writing is influential and that others view it as having worth (Reid \& Hresko, 1981). Learning to write requires tasks that are authentic (Hull, 1989). Writing must be presented not as a process that is an end in itself but, instead, as an activity that allows the author to accomplish some larger, authentic communicative purpose. Hull suggested that writers can acquire new knowledge and skills through "scaffolding," in which they are assisted in areas where their knowledge and skills are weak. 
Pressley, El-Dinary, and Brown (1992) described scaffolding as a multi-step process. First, teachers adjust their interactions with children to match the students' understanding of the concepts being taught. Initially, the teacher models and explains new skills and concepts and is largely responsible for controlling the students' interactions and activities. Control is gradually given to the student as he or she increases in competence. Additional adult intervention is provided whenever the student falters. Eventually the student can perform without assistance. Each time students are asked to attempt an authentic writing task, essentially they are being asked to do something they are not ready for and cannot do on their own except in a flawed, incomplete fashion (Hull, 1989). Scaffolding is necessary to allow students to participate in the writing process despite their level of skill.

Cole and Griffin (1986) adapted the instructional technique of "reciprocal questioning" from Brown, Palincsar, and Armbruster (1984) for writing instruction. Students worked in collaboration with adults so they could see the activities modeled by more knowledgeable others and, thus, they were gradually able to internalize this model.

Writing must be viewed as a process embedded in a context (Hull, 1989). This acknowledges that what counts as writing is socially constructed. Hull argued that writing depends upon social institutions and conditions for its meaning and its practice. This perspective potentially revolutionizes how writing is defined: What is valued as successful writing varies depending on what function that writing will serve, for which people, and at which time (Hull, 1989). People learn to write in social settings where reading and writing have certain purposes for the people involved (Langer, 1987). This viewpoint conceptualizes learning to write as enculturation into a community or a discipline (Hull, 1989). For example, different disciplines require different types of writing; writing a lab report is different from writing an English essay question. Students must be made aware of the varying expectations and conventions for the various types of writing they will do.

Exemplifying these concepts in writing instruction, Hull (1989) described instruction in a 9th-grade basic English class of low-achieving and special education students. The teacher approached writing instruction by treating her students as capable readers and writers, providing them with many occasions for literary activities and talk about cognitive and social processes (what students think they are gaining from writing, how they connect it to their lives outside the classroom, and what and why they are writing). The teacher stressed developing the students' ability to communicate in writing in ways that make sense to their audiences. Writing instruction was organized around the practice of letter writing. Class members were paired with members of an 11th- and 12th-grade general English class on the basis of interests they described in introductory essays. The upperclass members were supposed to write to the 9 th graders once a week with the intent of helping them improve their writing. The teacher gave the students no specific instructions on how to format their letters, nor did she direct them to rework their writings to improve content or mechanics. The teacher expected the 9th graders to: (a) see the upperclass writings as models of acceptable personal letters; (b) become engaged with a distant audience known only through written communication and provide someone other than the teacher who "cared" about their writing; (c) recognize writing as communication to reach an audience; (d) participate willingly and with a notion to "make sense" because of the audience; and (e) become engaged with communicating ideas by being willing to explain their own ideas in writing to help their audiences understand their meaning (Heath \& Branscombe, 1985).

Later in the school year, the purpose and audience for writing expanded in this classroom. The teacher arranged for the students to correspond with Shirley Brice Heath, an anthropologist living in California, on how they might become her "associates" as ethnographers of communication. With Heath's direction, the students began to take field notes on how language functions in their community. The idea was that these activities would make the students linguistically aware speakers and writers, give them practice in recording information, and give them a chance to be informed critics of their classmates' reports and interpretations of data. Students not only wrote letters to Heath; they also wrote field notes, fieldsite descriptions, autobiographical essays, personal essays, and explanatory essays analyzing their field notes. This correspondence with Heath allowed students to practice various types of communication: "(a) detailed explanations and assessments of past events, (b) descriptions of current scenes, actions, and people, and (c) arguments defending their course of action, point of view, or interpretation" (Heath \& Branscombe, 1985 , p. 20).

The students were able to carry out these challenging tasks because the teacher provided appropriate instructional scaffolding. Initially, students wrote to their peers about the here and now. Then, through their correspondence with Heath, they changed their discourse from personal to impersonal, from narrative to exposition, increasing the sophistication of their writing by modeling Heath's writing and by responding to her questions.

Results of this instructional program indicated that students had changed over the year from simply answering questions to initiating topics and sustaining commentary on them. As time went on, students wrote longer letters, and they read more as well: news items, magazines, stories, and novels. More important, the students' perceptions of writing changed. Previously, for these students, writing had meant worksheets on grammar and spelling. By participating in this authentic task of writing to a researcher, the students began to use writing to communicate to someone else information they had collected and interpreted. 


\section{Higher Order Thinking Skills and Mathematics}

The 1988 Mathematical Sciences Education Board's Curriculum Framework Task Force (cited in Schoenfield, 1989) proposed that mathematics education must focus on the development of mathematical power, which is defined as the ability to: (a) understand mathematical concepts and methods; (b) discern mathematical relations; (c) reason logically; and (d) apply mathematical concepts, methods, and relations to solve a variety of non-routine problems. A major weakness reported for the instruction of problem solving is that the questions asked in typical math texts are often so unreal that they reinforce the students' suspicions that math concepts and procedures are not truly useful in their everyday lives (Lesh, 1981). When students see little relationship between math and their own lives, they have no incentive to work on building networks of mathematical knowledge. They see no purpose for the information and have no need to organize or remember it.

Typically, math instruction in schools focuses primarily on procedures and does not aid the students in constructing the conceptual base needed to form a network between the procedures learned and mathematical conceptual knowledge. Students often are not shown how new concepts and theories can function as tools to simplify problem solving. In many situations, students simply memorize factual information with little appreciation of how it simplifies problem solving. These concepts and procedures are introduced out of context; thus, they are viewed as something complicated to learn rather than as tools that simplify problem solving. In contrast, when students encounter naturally occurring problems that create a need for the new information, it reinforces their view of the concepts and procedures as useful problem-solving tools.

Lesh (1981) described a project-oriented approach to math instruction wherein the child is creatively engaged in pursuit of a personally meaningful project. In the project-oriented approach, the student has a goal that requires solution of the problem and the subproblems within it. For example, a student attempts to learn how to find the best loan for buying a car, a problem requiring a great deal of mathematical knowledge. To meet this goal, the student works for extended periods to solve the numerous subproblems involved in learning how to determine how various interest rates affect the monthly payments as well as the total purchase price of the car. The student is willing to stay engaged in the task because it is personally meaningful and intrinsically motivating. Finally, it is a complex task that includes many subproblems.

The Adventures of Jasper Woodbury is a series of instructional materials composed of video, written, and optional computer materials developed by the Cognition and Technology Group at Vanderbilt (in press; Learning Technology Center, 1992), designed to be tools teachers can use to develop mathematics problem-solving skills. These skills include planning, formulating problems, finding and constructing information, mathematical calculation, and decision making. The
Adventures of Jasper Woodbury currently consists of six episodes, each of which is a narrative story that ends with a challenging problem for the students to solve. To do so, they use information presented in the story.

For example, in the third episode, The Big Splash, Jasper's young friend Chris wants to help his school raise money to buy a new camera for the school TV station. His idea is to have a dunking booth in which teachers are to be dunked when students hit a target. To obtain a loan for his project, he must develop a business plan for the school principal. The overall problem centers on developing this business plan, including the use of a statistical survey to help him decide if his idea would be profitable. The teacher shows this episode to the entire class. At the end of the episode is a challenge to the students to develop this business plan for the character, Chris. To do this, the entire group first brainstorms to identify subproblem questions that must be solved to complete the business plan. The entire group then breaks into small groups, whose members begin solving the subproblems. The students are encouraged to look back in the video to locate information and data they need to solve the subproblems.

The small groups work for several class sessions to solve these subproblems and to come up with the solution to the challenge, the business plan. The small groups share their solutions with the rest of the class, and the entire class discusses the solutions proposed and the processes the groups went through to obtain these solutions. Then the entire class watches the video solutions in which Chris explains and demonstrates how he developed his business plan. The class can compare and contrast their solutions with the video solution.

The next step in the Jasper instructional program is to have the students solve similar problems, known as analogous problems, also presented on the videodisc. These take the original Jasper story problem and alter it in various ways to create new problems designed to: (a) give students additional experience solving subproblems similar to those found in the solution to the adventure, and (b) extend their learning into related math and science areas. Sometimes information has simply been changed and the students are asked to recalculate part of the solution or discuss how changes might affect the solution. Other times new information is added and students are asked to discuss or calculate how this new information might impact the solution. The purpose of these analogous problems is to facilitate generalization of the knowledge and procedures used in the Jasper story problem to other, similar situations.

\section{MODIFICATIONS FOR STUDENTS WITH DISABILITIES}

If students with disabilities are to be involved in higher order thinking and problem solving, a concern that arises is how teachers can involve students who lack basic skills in holistic, 
meaningful activities. Characteristically, students with mild disabilities are passive and unmotivated and do not fare well in unstructured learning situations. For these reasons, Harris and Pressley (1992) caution against taking an extreme constructivist approach to teaching these students. Although learning by discovery may be motivating to students, without guidance they might engage in "errorful knowledge construction" based on misunderstanding or incorrect information. Direct instruction in cognitive and metacognitive strategies is necessary to avoid this pitfall. During the initial phases of teaching higher order skills, Borkowski and Muthukrishna (1992) say, the teacher must be extensively involved in the instruction. They advocate explicit, direct explanations that incorporate modeling, teacher-guided practice (which includes the frequent use of cues, elaboration and re-explanation), and extensive elaborative feedback to the learner. Data reported by Elliot-Faust, Pressley, and Dalecki (1986) indicate that this approach is superior to simply asking students to infer relationships. Though on the surface this approach seems incompatible with an approach based on a constructivist view of learning, one must consider that the purpose of the direct teaching approach is to build a foundation on which the student can construct additional knowledge.

\section{REFERENCES}

Anderson, L. M. (1989). Implementing instructional programs to promote meaningful, self-regulated learning. In J. E. Brophy (Ed.), Advances in research on teaching (Vol. 1, pp. 311-341). Greenwich, CT: JAI Press.

Ausubel, D. P., Novak, J. D., \& Hanesian, H. (1978). Educational psychology. New York: Holt, Rinehart \& Winston.

Borkowski, J. G., \& Muthukrishna, N. (1992). Moving metacognition into the classroom: Working models and effective strategy teaching. In M. Pressley, K. R. Harris, \& J. T. Guthrie (Eds.), Promoting academic competence and literacy in school (pp. 477-501). San Diego: Academic Press.

Bransford, J. D., Kinzer, C., Risko, V., Rowe, D., \& Vye, N. (1989). Designing invitations to thinking: Some initial thoughts. Cognitive and social perspectives for literacy research and instruction. 38th Yearbook-National Reading Conference (pp. 35-54). Chicago: National Reading Conference.

Bransford, J. D., Sherwood, R. D., Hasselbring, T. S., Kinzer, C. K., \& Williams, S. M. (1990). Anchored instruction: Why we need it and how technology can help. In D. Nix, \& R. Spiro (Eds.), Cognition, education, and multimedia: Exploring ideas in high technology (pp. 115-141). Hillsdale, NJ: Lawrence Erlbaum Associates.

Bransford, J. D., Sherwood, R. D., Vye, N. J., \& Rieser, J. (1986). Teaching thinking and problem solving: Suggestions from research. American Psychologist, 41(10), 1078-1089.

Bransford, J. D., \& Vye, N. J. (1989). A perspective on cognitive research and its implications for instruction. In L. B. Resnick \& L. E. Klopfer (Eds.), Toward the thinking curriculum: Current cognitive research (pp. 173-205). Pittsburgh, PA: Association for Supervision \& Curriculum Development.

Brown, A. L., Campione, J. C., \& Day, J. D. (1981). Learning to learn: On training students to learn from texts. Educational Researcher, 10, $14-20$.
Brown, A. L., Palincsar, A. S., \& Armbruster, B. B. (1984). Introducing comprehension-fostering activities in interaction learning situations. In H. Mandl, N. Stein, \& T. Trabasso (Eds.), Learning and comprehension of texts (pp. 255-286). Hillsdale, NJ: Erlbaum.

Carnine, D. (1991). Curricular interventions for teaching higher order thinking to all students: Introduction to a special series. Journal of Learning Disabilities, 24(5), 261-269.

Champagne, A. B., Klopfer, L., \& Gunstone, R. F. (1985). Effecting changes in cognitive structure among physics students. In A. L. Pines \& L. H. T. West (Eds.), Cognitive structure and conceptual change (pp. 163-188). New York: Academic Press.

Cognition and Technology Group at Vanderbilt. (1990). Anchored instruction and its relationship to situated cognition. Educational Researcher, 19(3), 2-10.

Cognition and Technology Group at Vanderbilt. (in press). Integrated media: Toward a theoretical framework for utilizing their potential. Journal of Special Education Technology.

Cole, M., \& Griffin, P. (1986). A sociohistorical approach to remediation. In S. de Castell, A. Luke, \& K. Egan (Eds.), Literacy, society and schooling: A reader (pp. 110-131). Cambridge, MA: Cambridge University Press.

Derry, S. J. (1990). Remediating academic difficulties through strategy acquisition: The acquisition of useful knowledge. Remedial \& Special Education, 11(6), 19-31.

Elliot-Faust, D. J., Pressley, M., \& Dalecki, L. B. (1986). Process training to improve children's referential communication: Asher and Wugfield (1981) revisited. Journal of Educational Psychology, 78, 22-26.

Englert, C. S., Tarrant, K. L., \& Mariage, T. V. (1992). Defining and redefining instructional practice in special education: Perspectives on good teaching. Teacher Education \& Special Education, 15(2), 62-86.

Glaser, E. M. (1985). Critical thinking: Educating for responsible citizenship in a democracy. National Forum, 65, 24-27.

Goodman, Y. M., \& Burke, C. (1981). Reading strategies: Focus on comprehension. New York: Holt, Rinehart \& Winston.

Harris, K. R., \& Pressley, M. (1992). The nature of cognitive strategy instruction: Interactive strategy construction. Exceptional Children, 57(5), 392-404.

Hasselbring, T. S., Goin, L. I., \& Bransford, J. D. (in press). Examining the cognitive challenges and pedagogical opportunities of integrated media systems: Toward a research agenda. Journal of Special Education Technology.

Heath, S. B., \& Branscombe, A. (1985). 'Intelligent writing' in an audience community: Teacher, students, and researcher. In S. W. Freedman (Ed.), The acquisition of written language: Response and revision (pp. 3-32). Norwood, NJ: Ablex.

Hull, G. A. (1989). Research on writing: Building a cognitive and social understanding of composing. In L B. Resnick \& L. E. Klopfer (Eds.), Toward the thinking curriculum: Current cognitive research (pp. 104-128). Pittsburgh, PA: Association for Supervision \& Curriculum Development.

Kinzer, C., Rieth, H., \& Singer-Gabella. (1992). An integrated curriculum and life-style knowledge approach to literacy and social studies instruction for students with mild disabilities. Washington, DC: Special Education Programs.

Lampert, M. (1990). When the problern is not the question and the solution is not the answer: Mathematical knowing and teaching. American Research Journal, 27, 29-64.

Langer, J. A. (Ed.). (1987). Language, literacy, and culture: Issues of society and schooling. Norwood, NJ: Ablex.

Learning Technology Center. (1992). The adventures of Jasper Woodbury. Optical Data Corp.

Lesh, R. (1981). Applied mathematical problem solving. Educational Studies in Mathematic 
Moore, P. R. (1988). The design and development of a hypermedia curriculum to teach time concepts. Paper presented at Council for Exceptional Children Technology and Media Division National Conference, Reno, NV.

Nickerson, R. S. (1987). Why teach thinking? In J. B. Baron \& R.J. Sternberg (Eds.), Teaching thinking skills: Theory and practice (pp. 27-37). New York: W. H. Freeman \& Co.

Palincsar, A. S. (1990). Providing the context for intentional learning. Remedial and Special Education, 11(6), 36-39.

Palincsar, A. S., \& Brown, A. L. (1989). Instruction for self-regulated reading. In L. B. Resnick \& L. E. Klopfer (Eds.), Toward the thinking curriculum: Current cognitive research (pp. 19-39). Pittsburgh, PA: Association for Supervision \& Curriculum Development.

Paris, S. G., \& Winograd, P. (1990). Promoting metacognition and motivation of exceptional children. Remedial \& Special Education, 11(6), $7-15$.

Pea, R. D., \& Soloway, E. (1987). Mechanisms for facilitating a vital and dynamic education system: Fundamental roles of education science and technology (Final Report). Washington, DC: Office of Technology Assessment.

Pogrow, S. (1990). The HOTS approach to using computers with at-risk students: A description of the teaching and curricular techniques used in the HOTS program. Tucson, AZ: Thinking with Computers.

Pressley, M., Borkowski, J. G., \& Schneider, W. (1987). Cognitive strategies: Good strategy users coordinate metacognition and knowledge. In R. Vasta \& G. Whitehurst (Eds.), Annuals of child development (Vol. 4, pp. 80-129). Greenwich, CT: JAI Press.

Pressley, M., El-Dinary, P. B., \& Brown, R. (1992). Skilled and not-soskilled reading: Good information processing and not-so-good information processing. In M. Pressley, K. R. Harris, and J. T. Guthrie (Eds.), Promoting academic competence and literacy in school (pp. 92-127). San Diego: Academic Press.

Reid, D. K., \& Hresko, W. P. (1981). A cognitive approach to learning disabilities. New York: McGraw-Hill Book Co.

Resnick, L. B. (1987). Education and learning to think. Washington, DC: National Academy Press.

Resnick, L. B., \& Klopfer, L. E. (1989). Toward a thinking curriculum: An overview. In L. B. Resnick \& L. E. Klopfer (Eds.), Toward the thinking curriculum: Current cognitive research (pp. 1-18). Pittsburgh, PA: Association for Supervision \& Curriculum Development.

Risko, V. J., Kinzer, C., Goodman, J., McLarty, K., Dupree, A., \& Martin, H. (1989). Effects of macrocontext on reading comprehension, composition of stories, and vocabulary development. Paper presented at meeting of the American Research Associates, San Francisco.

Schoenfield, A. H. (1989). Teaching mathematical thinking and problem solving. In L. B. Resnick \& L. E. Klopfer (Eds.), Toward the thinking curriculum: Current cognitive research (pp. 83-103). Pittsburgh, PA: Association for Supervision \& Curriculum Development.
Schumaker, J. B., Deshler, D. D., \& Ellis, E. S. (1986). Intervention issues related to the education of $\mathrm{LD}$ adolescents. In J. D. Torgesen \& B. Y. Wong (Eds.), Learning disabilities: Some new perspectives (pp. 329-365). New York: Academic Press.

Smith, E. B., Goodman, K. S., \& Meredith, R. (1976). Language and thinking in school. New York: Holt, Rinehart \& Winston.

Whitehead, A. N. (1929). The aims of education. New York: Macmillan.

\section{ADDITIONAL REFERENCES}

Anderson, J. R. (1983). The architecture of cognition. Cambridge, MA: Harvard University Press.

Beck, I. (1989). Improving practice through understanding reading. In L. B. Resnick \& L. E. Klopfer (Eds.), Toward the thinking curriculum: Current cognitive research (pp. 40-58). Pittsburgh, PA: Association for Supervision \& Curriculum Development.

Beck, I. (1986). Using research on reading. Educational Leadership, 43, $13-15$.

Dweck, C. S., \& Elliot, E. S. (1983). Achievement motivation. In E. M. Hetherington (Ed.), Handbook of child psychology (Vol. 4, pp. 643-691). New York: Wiley.

Ennis, R. H. (1987). A taxonomy of critical thinking dispositions and abilities. In J. B. Baron \& R. J. Sternberg (Eds.), Teaching thinking skills: Theory and practice (pp. 9-26). New York: W. H. Freeman and Co.

Gagne, E. D. (1985). The cognitive psychology of school learning. Boston: Little, Brown.

Gagne, R. M. (1985). The conditions of learning (4th ed.). New York: Holt, Rinehart \& Winston.

Goodman, K. S., \& Goodman, Y. (1976, April). Learning to read is natural. Paper presented at Conference on Theory and Practice of Beginning Reading Instruction, Pittsburgh, PA.

Kinney, J. K. (1980). Why bother? The importance of critical thinking. In R. E. Young (Ed.), Fostering critical thinking (pp. 1-10). San Francisco: Jossey-Bass.

Mandl, H., Stein, N. L., \& Trabasso, T. (Eds.), Learning and comprehension of text. Hillsdale, NJ: Erlbaum.

Mastropieri, M., \& Scruggs, T. (1987). Effective instruction in special education. College Hill Press.

Perl, S. (1979). The composing processes of unskilled college writers. Research in the Teaching of English, 13, 317-336.

Smith, F. (1973). Psycholinguistics and reading. New York: Holt, Rinehart \& Winston.

Stein, N. L., \& Trabasso, T. (1982). What's in a story: An approach to comprehension and instruction. In R. Glaser (Ed.), Advances in instructional psychology (Vol. 2, pp. 213-267). Hillsdale, NJ: Erlbaum.

Young, R. E. (1980). Fostering critical thinking. San Francisco: JosseyBass.

\section{PERMISSIONS AND COPYRIGHT}

All rights are reserved. No part of this publication may be reproduced, photocopied, faxed, stored in a retrieval system, or transmitted, in any form or by any means, electronic, mechanical, recording or otherwise, without the prior written permission of the publisher.
Back issues are available for sale. Reproduction requires permission and payment of fees. It is illegal and a violation of Federal copyright law to reproduce this publication without permission. Direct all inquiries to the permissions editor. 